\title{
Homegardens (Aal-oos-gad) of the Basket People of Southwestern Ethiopia: Sustainable agro-ecosystems characterizing a traditional landscape
}

\section{Research}

\section{Abstract}

Traditional agricultural landscapes support substantial levels of biological and cultural diversity. Tropical homegardens, which represent sustainable agro-ecosystems, are important components of such landscapes. In this study, homegardens of Basketo Special Woreda of Southwestern Ethiopia have been investigated. The study aims at understanding organization of homegardens, their role in maintenance of biological diversity and also the impact of ongoing changes on the composition and function of the gardens. A total of 60 homegardens (households) were sampled from 12 k'ebele (the smallest administrative unit) selected by employing a combination of purposive and stratified sampling methods. In the study, issues that pertain to local resource perception, management, and use norms as well as plant diversity of the different land-use systems in the landscape are addressed. A total of 207 species, of which 149 are maintained in the homegardens, were recorded from the managed landscape. Biodiversity has been cultivated in these farming units as a result of the farmers' innate perception of biodiversity value and also due to the characteristic organization of the gardens which promote concentration of plant species. Currently, Basketo homegardens are undergoing unusual dynamics mainly due to market-driven factors. Some crops such as coffee/buna (Coffea arabica L.), which bring better economic return, are expanding and displacing enset/uuts (Ensete ventricosum (Welw.) Cheeseman) (which traditionally forms the basic element of the garden) and other long-existed crops. Drastic alteration of these crop production units could lead to unwanted impacts including a serious deterioration of biological diversity and loss of the sustainability feature of the agro-ecosystems.

\section{Introduction}

Tropical homegardens are production units that usually occupy small plots of land surrounding the house and in which a mixture of perennials, annual crops, and also animals are raised (Christanty 1990, Fernandes \& Nair 1990, Godbole 1997, Peyre et al. 2006, Power \& Flecker 1996). These agro-ecosystems represent one of the oldest farming practices found throughout the world, varying greatly with climate and local custom (Ali 2005, Capistrano \& Marten 1986, Soemarwoto \& Conway 1992).

Homegardens are known to serve a number of functions to the household. They allow an almost year-round production of food due to the diverse crops maintained; are sources of products such as medicinal plants, construction materials, fuel, and beauty aids; are important in generating income to the household; make use of the local labor thereby making people engaged; have a role

\section{Correspondence}

Feleke Woldeyes, Department of Biology, Arba Minch University, P.O. Box 21, Arba Minch, ETHIOPIA. felekewoldeyes@yahoo.com

Zemede Asfaw, National Herbarium, Addis Ababa University, P.O. Box 3434, Addis Ababa ETHIOPIA zemede.asfaw@aau.edu.et

Sebsebe Demissew, National Herbarium, Addis Ababa University, P. O. Box 3434, Addis Ababa ETHIOPIA. sebsebe.demissew@aau.edu.et

Bernard Roussel, Muséum National d'Histoire Naturelle, 57, rue Cuvier, 75231 Paris Cedex 05, Paris, FRANCE. roussel@mnhn.fr

Ethnobotany Research \& Applications 14:549-563 (2016)

Published: 17 January 2016

http://dx.doi.org/10.17348/era.14.0.549-563 
in strengthening the social bonds among community members; serve as a symbol of status; and are also valuable sites for agrobiodiversity conservation (Angel-Perez \& Mendoza 2004, Asfaw 2001b, Christanty 1990, Fernandes \& Nair 1990, Finerman \& Sackett 2003, Karyono 1990, Nguyen 1995, Soemarwoto \& Conway 1992, Tesfaye 2008, Wezel \& Bender 2003, Woldeyes 2000).

Homegardens that are closely tied to local world views (Curry 2000) acquire highly complex structures, especially in the humid tropics (Ker 1995). Tropical homegardens are usually described in terms of three interrelated features: architecture, diversity, and sustainability. The production units are intelligent in their basic pattern and carefully structured (Fernandes \& Nair 1990, Gillespie et al. 1993), displaying a discernible architecture. Component plants, that are integrated into the system based on an understanding of the requirements of each species and with the intention of obtaining maximized yields (Abdoellah 1990), are arranged in the garden both in horizontal and vertical fashion. High agrodiversity is a typical feature of tropical homegardens and hence they are labeled as agro-ecosystems with the highest biological diversity and complexity (Brownrigg 1985, Okigbo 1990, Soemarwoto 1987). The unique organization and high biological diversity maintained in homegardens is recognized to have resulted in sustainability (both ecological and social) features displayed by the agro-ecosystems (Peyre et al. 2006).

Ethiopia is one of the countries where homegardening is practiced. The agricultural practice is believed to be as old as agriculture in the country (Asfaw 2001b, Asfaw \& Nigatu 1995). The assumption is closely tied to the notion that enset/uuts, the indigenous tuber crop that constitutes a major component of home gardens, has been in cultivation since 7000 years ago in the southwestern highlands of the country (Brandt 1996, Ehret 1979). Given that Ethiopia is a country characterized by diverse climatic, altitudinal, and socio-cultural conditions, it is not difficult to envisage existence of various types of homegardens. Two broad categories of Ethiopian homegardens are recognized: small-sized gardens in cereal-crop-based farming areas and enset-based, medium-to-large-sized gardens of the southern and southwestern parts of the country (Abebe 2005, Asfaw 2001a).

Enset-based homegardens of southern and southwestern Ethiopia, which are characterized by the concurrent cultivation of diverse plants, are of considerable importance in fulfilling household needs to the largely agrarian local population. However, the actual value of these land-use systems appears not to have been properly comprehended. Such misconception has led to research and development activities geared toward transforming homegardens into conventional farming systems with the aim of attaining increased yields (Kippie 2002). Growing interest in acquiring insight into the role of human-man- aged ecosystems in conservation, mainly after the Convention on Biological Diversity, has stimulated research in the area, and a number of studies (Abebe 2005, Agize 2008, Kippie 2002, Tesfaye 2008, Wassihun et al. 2003, Woldeyes 2000) have been conducted on the homegardens of southwestern Ethiopia. Nevertheless, these studies mainly emphasized documenting garden characteristics, role in subsistence, management practices, and to some extent the dynamics of the system. In the present study, an attempt is made to analyze these systems with a broader perspective (i.e., in the context of the entire landscape) by giving proper importance to local perceptions. This paper, therefore, addresses the questions: (1) Are homegardens of Basketo ingeniously designed production units? (2) What is the contribution of homegardens in supporting biodiversity as landscape components? (3) What lends sustainability to Basketo homegardens? (4) How are Basketo homegardens changing?

\section{Methods}

\section{The study area}

The study was conducted in Basketo Special Woreda of the South Nations, Nationalities, and Peoples Regional State (SNNPRS), Ethiopia (Figure 1). The study site was selected on the basis of preliminary observations. Basketo Special Woreda is among the less accessible localities in the country where farming and other cultural practices remain relatively intact. Since homegardening is the major farming activity and the major staples-enset/uuts, buuy (Dioscorea sp.), and sherkka (Colocasia esculenta (L.) Schott)—as well as the two major cash crops, coffee/buna and okasha/koroorima (Aframomum corrorima (A.Braun) P.C.M.Jansen), are integrated into the system, conducting the study in Basketo was assumed to provide original information on traditional homegardens.

The main town of Basketo, Laska (06¹8' N, 36³7'E; 1860 masl), is located $581 \mathrm{~km}$ southwest of Addis Ababa. The total land area of Basketo is $2382.35 \mathrm{~km}^{2}$ with altitudes ranging from 700 to $2200 \mathrm{~m}$. Following the agro-ecological zone classification scheme by MoA (2000), Basketo falls into the tepid to cool sub-humid mid-highlands subzone, which is characterized by fertile soils and a conducive climate for plant and animal growth. The mean annual rainfall of the area is $1376 \mathrm{~mm}$ with a $1578 \mathrm{~mm}$ maximum, and the rain exhibiting a two-peak pattern. Basketo Special Woreda is inhabited mainly by members of the Basket ethnolinguistic group which belongs to the Omotic language family.

\section{Data collection}

Investigations were conducted by employing ethnobotanical methods, the details of which are presented below. Ethical considerations pertinent to 


\section{Woldeyes et al. - Homegardens (Aal-oos-gad) of the Basket People of Southwestern Ethiopia}

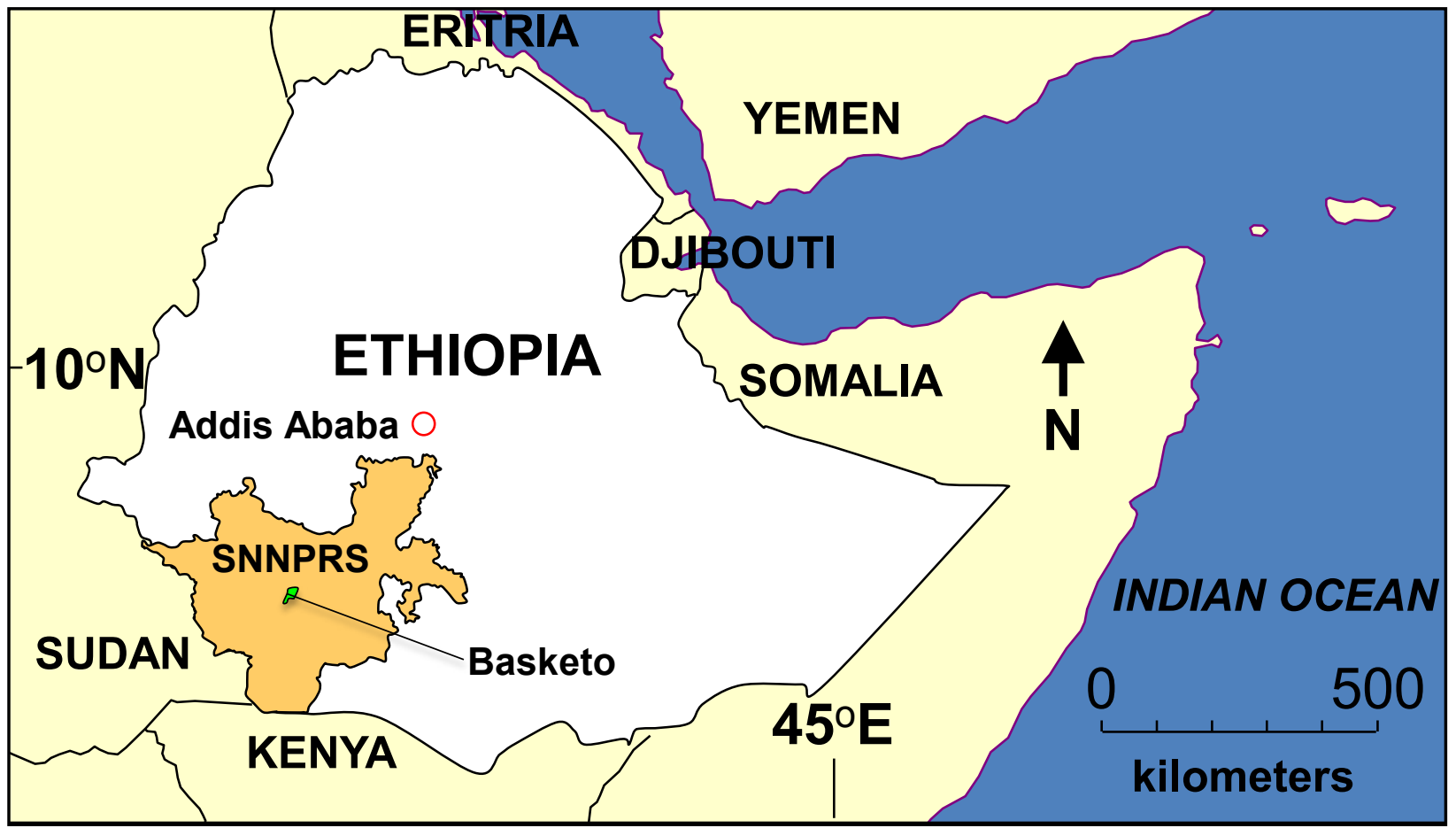

Figure 1. Basketo Special Woreda, South Nations, Nationalities, and Peoples Regional State (SNNPR), Ethiopia.

ethnobotanical research were made from the beginning of the study as this is crucial in such an undertaking (Alexiades 1996, Cunningham 1996). Accordingly, all concerned bodies along the administrative hierarchy (i.e., zonal, woreda, and k'ebele officials) and also local community members were informed about the research, and prior informed consent was obtained. The study was conducted at two levels: households/homegardens were used as a unit for investigation of local resource perception, use, and management, while data on floristic composition was collected from the different components (land-use systems) of the landscape.

Twelve k'ebele out of the total 30 were sampled from three altitudinal zones: low $(<1500 \mathrm{~m})$, medium $(1500$ $1900 \mathrm{~m}$ ), and high (>1900 m). The intention of sampling k'ebele from different altitudinal levels was to capture possible variations in the nature of homegardens and other aspects. A total of 60 homegardens (households) were sampled from the selected k'ebele by employing a combination of purposive and stratified sampling methods.

The garden survey at each household included recording plant species in the garden that were mentioned to have any use to the household. Voucher specimens of plants were collected and some were photographed. Semi-structured interviews were conducted during the different visits to the households focusing on different aspects: uses of plants in the garden, history of the garden, observed change on homegarden composition, perception and valuing of diversity, local resource use norm and manage- ment, and local belief-related practices. Focus group discussions were held to consolidate information obtained through household level interviews and also to generate new data. Group discussions were held with groups of people. Participants of the group discussions, who belonged to different age groups and sexes, were selected by applying snowball sampling (Bernard 2002) and also inviting people from neighboring k'ebele who converge at village markets.

Data on floristic composition was collected from the 60 homegardens as well as three other land-use systems (i.e., sacred groves, bamboo lands, and woodlands). Two approaches were followed while collecting plant-related data in homegardens. First, the entire homegarden was considered as a study unit and plant species were recorded. Then, arrangement and diversity of plants in the garden were studied systematically by laying a $4 \mathrm{~m} \times 5 \mathrm{~m}$ quadrat in two of the garden sections with three such quadrats along the third and longest section of the garden. Plant species and varieties present in each quadrat were recorded and percentage cover was estimated. This, in turn, was converted into cover-abundance values according to a modified Braun-Blanquet scale (van der Maarel 1979). The vertical arrangement of plants in the gardens was observed by taking note of height of plants constituting the different layers.

Information on plants of other land-use systems was collected through guided field interviews. In each land-use type, $10 \mathrm{~m} \times 20 \mathrm{~m}$ quadrats were laid to sample the flo- 
ristic composition. Names of all woody species and some herbaceous forms that were described to have local use were recorded, and species abundance and the pattern of stratification were noted. Voucher specimens of plants encountered during the survey were collected. Plant specimen identification and determination tasks were done at the National Herbarium (ETH).

\section{Data analysis}

Microsoft Office Excel 2003 was used for organizing data collected from the field into analyzable forms, for presenting data in tables and graphs, and to perform descriptive statistical analyses.

Different measures of diversity were used to assess the level of biological diversity at different scales. Alpha diversity (i.e., species richness) was determined by recording plant species in a study unit, whereas gamma diversity was obtained by summing all species encountered at a study area level. Shannon diversity index $\left(H^{\prime}\right)$, evenness $(\mathrm{E})$, and Sorensen's similarity index (Sc) (for measuring floristic similarity between the different land-use systems) were calculated following Magurran (2004) through equations:

$$
H^{\prime}=-\sum p_{i} \ln p_{i}
$$

where, $p_{i}$ is the proportion of individuals of the $i^{\text {th }}$ species;

$$
E=\frac{H^{\prime}}{H_{\max }}=\frac{H^{\prime}}{\operatorname{lnS}}
$$

where, $\mathrm{H}_{\max }$ is the maximum level of diversity possible within a given population, and $S$ is number of species; and

$$
\mathrm{Sc}=\frac{2 \mathrm{C}}{(\mathrm{A}+\mathrm{B})_{\mathrm{x}}},
$$

where, $C$ is the number of species common to both land-use types while A and B are number of species recorded from each land-use type.

In addition to descriptive statistics, one-way ANOVA was used to test the variation in diversity of garden sections. The statistical software package SPSS version 15.0 was employed for the analysis.

\section{Results}

\section{Organization of homegardens}

In Basketo, where the landscape is characterized by rolling hills, the homegarden (aal-oos-gad) stretches from the top, leveled part of a hill down to the wetland at the foot of the hill. Basketo homegardens are usually oblong (i.e., longer than wide) and divided into four parts relative to the living house (Figure 2). The elevated part of the garden that stretches from the house up to a fence is called aldira; the area that stretches from the house descending down to the wetland is alts'ana; the front part of the house is alkara/kara; whereas the area behind the house

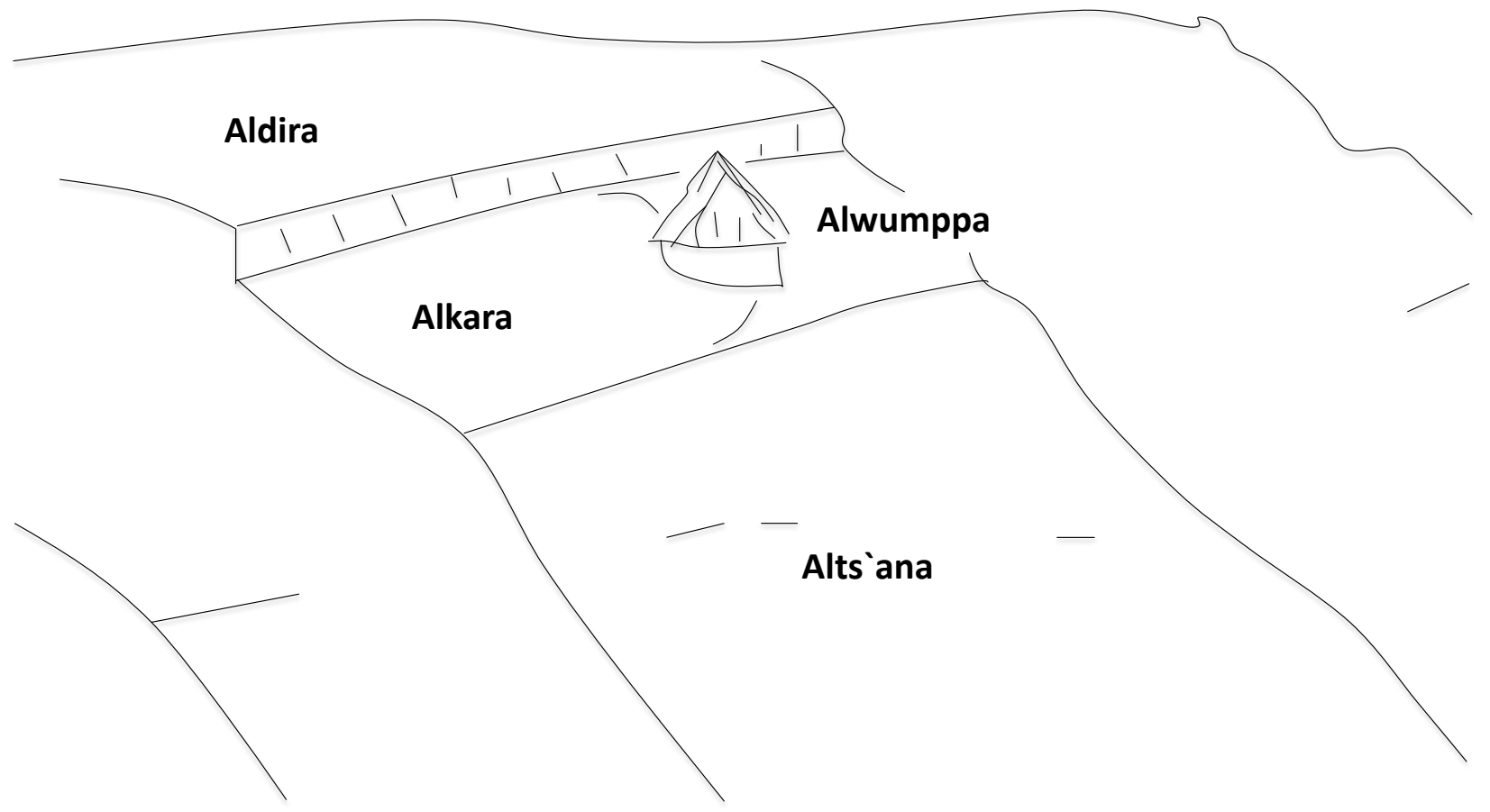

Figure 2. Organization of Basketo homegarden, Basketo Special Woreda, South Nations, Nationalities, and Peoples Regional State, Ethiopia. 


\section{Woldeyes et al. - Homegardens (Aal-oos-gad) of the Basket People of Southwestern Ethiopia}

is alwumppa/wumppita. Each garden section has specific characteristics and functions (Table 1).

In Basketo homegardens, a characteristic arrangement of plants is discernible not only in horizontal fashion but also vertically as canopy layers. Component plant species are arranged in a multilayered manner, and about three strata (lower, middle, upper) can be identified, although a clear distinction of the layers may not be obvious all of the time (Table 2).

\section{Use of homegardens}

The functions of Basketo homegardens are diverse, ranging from providing food and other necessary materials for subsistence to serving as a place to live and maintain a traditional lifestyle, cultural values, and social relations. The household relies on homegarden plants for its food supply except for some supplementary produce coming from the crop fields. Diverse crops with different flowering, fruiting, and harvesting seasons and household animals fulfill this requirement. Uuts is the major staple food, supplemented by additional tuber crops (sherkka, buuy, dona (Ipomoea batatas (L.) Lam.)), vegetables, cereals, and spices. The other function of Basketo homegardens is related to health. Out of 149 plant species recorded from the homegardens, $32(21.5 \%)$ are used for medicinal purposes. Homegardens are also a source of construction materials, fuel, and beauty aids. Income generation is a growing role of homegardens, bringing a far-reaching impact to the nature of the agro-ecosystems.

The role of Basketo homegardens goes beyond providing material and monetary benefits. The agro-ecosystems also serve a number of social functions. In the first place, they signal the status of the household. A well-managed homegarden, for example, is known to belong to a respected person of high status or a strong and clever farmer, even by a passerby. A young man who owns a good homegarden has a better chance of success when soliciting a spouse. Since cultural activities such as religious rituals, wedding ceremonies, mourning, and dispute settlements take place within the homegarden area, homegardens constitute a place for cultural exchange, teaching of rules, and transmission of traditions from generation to generation.

Homegarden resources that range from produce to seedlings are shared, to a limited extent, among community members since such resources are perceived to belong to the household and at the same time to the community. The exchange of resources is based on the principle of reciprocity and the intention of ensuring the perpetuation of the resource in the landscape. In other words, resourc-

Table 1. Features, characteristic plants, and functions of Basketo homegardens in Basketo Special Woreda, South Nations, Nationalities, and Peoples Regional State, Ethiopia.

\begin{tabular}{|c|c|c|}
\hline Sections & Characteristic features and plants & Functions \\
\hline $\begin{array}{l}\text { alkara / kara } \\
\text { (front part) }\end{array}$ & $\begin{array}{l}\text { - Leveled land; open and clean space at the front of the } \\
\text { house; left unplanted }\end{array}$ & $\begin{array}{l}\text { - Place for social activities (wed- } \\
\text { ding, mourning) } \\
\text { - Site for product processing } \\
\text { (threshing crops, drying ) } \\
\text { - Place to feed and rest cattle }\end{array}$ \\
\hline $\begin{array}{l}\text { aldira } \\
\text { (elevated } \\
\text { part) }\end{array}$ & $\begin{array}{l}\text { - Elevated portion of the garden; dominated by uuts (Ensete } \\
\text { ventricosum (Welw.) Cheeseman), some big trees, and } \\
\text { buna (Coffea arabica L.); men's corner (until recently) } \\
\text { - Planted with high quality varieties of uuts, buna, Afro- } \\
\text { carpus falcatus (Thunb.) C.N.Page, Syzygium guineense } \\
\text { (Willd.) DC., Ficus laurifolia Lam., Ficus vasta Forssk., and } \\
\text { Pycnostachys abyssinica Fresen. }\end{array}$ & $\begin{array}{l}\text { - Place for conducting rituals (kaa- } \\
\text { sha) } \\
\text { - Site for maintaining high quality } \\
\text { uuts varieties } \\
\text { - Sign of the strength (virility) of the } \\
\text { owner }\end{array}$ \\
\hline $\begin{array}{l}\text { alwumppa / } \\
\text { wumppita } \\
\text { (backside) }\end{array}$ & $\begin{array}{l}\text { - Backyard; spices and vegetables dominate; women's corner } \\
\text { - Planted with bakra (Ocimum basilicum L.), barbara (Cap- } \\
\text { sicum annuum L.), rue (Ruta chalepensis L.), deebba (Co- } \\
\text { riandrum sativum L)., z'alma (Zingiber officinale Roscoe), } \\
\text { mayts' (Brassica spp.), and botay (Cucurbita pepo L.) }\end{array}$ & $\begin{array}{l}\text { - The spice corner } \\
\text { - Site for propagating enset seed- } \\
\text { lings }\end{array}$ \\
\hline $\begin{array}{l}\text { alts'ana } \\
\text { (lower side) }\end{array}$ & $\begin{array}{l}\text { - Sloping land; cropping pattern changes along its length, } \\
\text { consists of dry and wet parts } \\
\text { - Planted with buna, buuy (Ipomoea batatas (L.) Lam.), ce- } \\
\text { reals, pulses, okasha/koroorima (Aframomum corrorima } \\
\text { (A.Braun) P.C.M.Jansen), sherkka (Colocasia esculenta } \\
\text { (L.) Schott), and wooshi (Yushania alpina (K.Schum.) } \\
\text { W.C.Lin - identified as Arundinaria alpinia K.Schum. by } \\
\text { Hedberg et al. 2009) }\end{array}$ & $\begin{array}{l}\text { - Place for production of food, cash } \\
\text { crops, and materials for construc- } \\
\text { tion }\end{array}$ \\
\hline
\end{tabular}


Table 2. Plant species forming different canopy layers of Basketo homegardens, Basketo Special Woreda, South Nations, Nationalities, and Peoples Regional State, Ethiopia.

\begin{tabular}{|c|c|c|c|}
\hline \multicolumn{4}{|c|}{ Plant species } \\
\hline \multicolumn{4}{|c|}{ Homegarden canopy layers } \\
\hline Ground & Lower & Middle & Upper \\
\hline \multicolumn{4}{|c|}{ Aframomum corrorima (A.Braun) P.C.M.Jansen } \\
\hline & \multicolumn{3}{|c|}{ Brassica spp. } \\
\hline & \multicolumn{3}{|c|}{ Capsicum annuum L. } \\
\hline & & & Carica papaya L. \\
\hline & & \multicolumn{2}{|c|}{ Coffea arabica L. } \\
\hline & \multicolumn{3}{|c|}{ Colocasia esculenta (L.) Schott } \\
\hline & \multicolumn{3}{|c|}{ Coriandrum sativum $\mathrm{L}$. } \\
\hline \multicolumn{4}{|c|}{ Cucurbita pepo L. } \\
\hline & & & Ensete ventricosum (Welw.) Cheeseman \\
\hline & \multicolumn{3}{|c|}{ Helianthus annuus L. } \\
\hline & \multicolumn{3}{|c|}{ Ipomoea batatas (L.) Lam. } \\
\hline \multicolumn{4}{|c|}{ Lagenaria siceraria (Molina) Standl. } \\
\hline & & & Mangifera indica L. \\
\hline & & \multicolumn{2}{|c|}{ Manihot esculenta Cranz } \\
\hline & & \multicolumn{2}{|c|}{ Musa acuminata $\times$ balbisiana Colla } \\
\hline & & & Persea americana Mill. \\
\hline & & \multicolumn{2}{|c|}{ Rhamnus prinoides L'Hér. } \\
\hline & & \multicolumn{2}{|c|}{ Ricinus communis $\mathrm{L}$. } \\
\hline & \multicolumn{3}{|c|}{ Ruta chalepensis L. } \\
\hline & & \multicolumn{2}{|c|}{ Saccharum officinarum L. } \\
\hline & & & Solanecio mannii (Hook.f.) C.Jeffrey \\
\hline & & & Vernonia amygdalina Delile \\
\hline & \multicolumn{3}{|c|}{ Xanthosoma sagittifolium (L.) Schott } \\
\hline \multicolumn{4}{|c|}{ Zingiber officinale Roscoe } \\
\hline & & Zea ma & \\
\hline
\end{tabular}

es (usually planting materials) are offered to others with the recognition that the household will, someday, require resources in the same manner. Because of this, maintaining a plant resource in several gardens is encouraged for this allows regaining a resource lost from a single farmer's plot.

Homegardens of Basketo provide ground for experimentation and learning. Most farmers try new crops by planting in their homegardens; some make observations on such aspects as the emerging of different varieties from the seeds of an individual of a species (e.g., uuts), whereas still others experiment, as some farmers did on germination of okasha/koroorima seeds, and established facts on germination characteristics of the spice-yielding plant that is usually vegetatively propagated. It is in the homegarden that youngsters (both girls and boys) learn about cultivating crops, harvesting, and processing skills that are crucial in their later life.

\section{Management of homegardens}

Diverse management practices that range from designing the spatial (vertical and horizontal) structure of the garden and maintaining soil fertility to planting and harvesting are performed in the homegarden. While most of the activities can be carried out by any household member, some are gender-centered because of religious and labor requirements. Accordingly, only men used to work in the aldira (the elevated garden section) where a spiritual ceremony, kaasha, is performed. This is a norm even today in some households of the elderly. Part of the garden at the back of the house (alwumppa) is a women's corner where men rarely enter. The remaining garden sections 


\section{Woldeyes et al. - Homegardens (Aal-oos-gad) of the Basket People of Southwestern Ethiopia}

are parts where all family members work. Generally, women plant vegetables and spices while men do the planting of uuts and buuy, which involves laborious digging of the ground. Maintaining soil fertility (using cattle manure and household rubbish) is mainly the responsibility of women. The application of the inputs depends on the type of garden section and the kind of crop planted. Exchange of homegarden resources also takes place between women except for seeds and cash crops such as okasha/koroorima, which are considered to be a man's domain.

Extraction (and also use) of products from the homegarden is performed according to an established norm and only after conducting rituals in the case of some seasonal crops. For example, kabba (Zea mays L.), buuy, t'ef (Eragrostis tef (Zucc.) Trotter), moss (Sorghum bicolor (L.) Moench), and goss (Hordeum vulgare L.) are harvested after conducting a thanksgiving ceremony (kaasha). In Basketo, where uuts is grown mainly for its tuber, some varieties of the crop are harvested during limited occasions: during festivals, when a respected guest is received, during the rainy season, and when there is shortage of food. Otherwise, even the dry leaves of the plant are not stripped off but wrapped around the pseudostem.

Basketo people restrict harvesting resources under some circumstances. During the dry period, for example, harvesting of uuts and buna leaves is either reduced or totally prohibited; z'alma and buuy are not harvested at all; and entering into the okasha/koroorima stand is forbidden. The Basketo people refrain from cutting bamboo when the moon is visible. Harvesting takes place only during moonless days, i.e., during the period from the old moon set to the time when the new moon rises. It is believed that bamboo stems would experience weevil attack if cut outside the prescribed period. Another tradition is to avoid early harvesting of bigger uuts individuals and large corncobs, letting them stay for later use.

\section{Patterns of homegarden development and evolution}

In Basketo, where only limited land is available, a youngster starts his garden on his father's plot. Uuts is the first to be planted, followed by buna planted under the shade the pioneer (uuts) provides. Vegetables, tubers, pulses, spices, cereals, fruit crops, and other trees are gradually incorporated into the different parts of the garden. As older uuts individuals are harvested, buna gradually takes over the space. During the second round of planting, uuts is placed on the lower part of the garden next to the buna stand. In a mature garden, therefore, buna dominates areas close to the house except at the backyard whereas the relatively short-lived perennial uuts keeps moving away from the house. This, in turn, may necessitate moving the house to a new location closer to the uuts stand.
Table 3. Recent plant introductions to Basketo gardens Basketo Special Woreda, South Nations, Nationalities, and Peoples Regional State, Ethiopia, from sources outside of the community. Three species not from outside sources but incorporated into the garden from the local natural vegetation are shown in blue.

\begin{tabular}{|c|c|c|}
\hline Origin & Species & Use \\
\hline E. Africa & Aloe macrocarpa Tod. & \\
\hline Americas & Ananas comosus (L) Merr. & fruit \\
\hline Americas & Arachis hypogea L. & fruit \\
\hline Eurasia & Artemisia annua L. & spice \\
\hline Eurasia & Beta vulgaris L. & \\
\hline Eurasia & Brassica oleracea L. & \\
\hline Americas & Carica papaya L. & fruit \\
\hline Americas & Casimiroa edulis La llave & fruit \\
\hline Oceania & Casuarina sp. & \\
\hline E. Africa & $\begin{array}{l}\text { Catha edulis (Vehl.) Forssk. ex } \\
\text { Endl. }\end{array}$ & \\
\hline Asia & Citrus sinensis (L.) Osbeck & fruit \\
\hline Americas & Cupressus Iusitanica Mill. & \\
\hline Asia & Curcuma longa L. & spice \\
\hline Americas & $\begin{array}{l}\text { Cyphomandra betacea (Cav.) } \\
\text { Sendtn. }\end{array}$ & fruit \\
\hline Eurasia & Daucus carota L. & \\
\hline Americas & Euphorbia cotinifolia L. & \\
\hline Americas & $\begin{array}{l}\text { Euphorbia pulcherrima Willd. ex } \\
\text { Klotzsch }\end{array}$ & \\
\hline W. Africa & $\begin{array}{l}\text { Fagaropsis angolensis (Engl.) } \\
\text { H.M.Gardner }\end{array}$ & spice \\
\hline Oceania & Grevillea robusta A.Cunn. ex R.Br. & \\
\hline Eurasia & Lupinus albus L. & \\
\hline Eurasia & Malus sylvestris (L.) Mill. & fruit \\
\hline Asia & Mangifera indica L. & fruit \\
\hline Americas & Manihot esculenta Granz & \\
\hline Eurasia & Mentha spicata L. & spice \\
\hline Asia & $\begin{array}{l}\text { Musa acuminata } \times \text { balbisiana Colla } \\
(2 \text { new varieties) }\end{array}$ & fruit \\
\hline Americas & Persea americana Mill. & fruit \\
\hline Americas & Psidium guajava L. & fruit \\
\hline Americas & Sesbania sesban (L.) Merr. & \\
\hline S. Africa & Vepris dainellii (Pic. Serm.) Mziray & spice \\
\hline Americas & $\begin{array}{l}\text { Xanthosoma saggitifolium (L.) } \\
\text { Schott }\end{array}$ & \\
\hline
\end{tabular}


As the results of this study indicate, noticeable changes have already started to occur with respect to the structure and composition of Basketo homegardens. Out of 149 Basketo homegarden species, $30(20.1 \%)$ were introduced into the garden system during the last 15-20 years. Fruits, ornamentals, and spices account for the most introductions into gardens (Table 3). The number of species introduced per garden ranges from 4 to 15 , with an average introduction rate for the whole study area of 8.4 and no significant difference between villages of the three altitudinal zones $(p=0.513)$ (Table 4).

Enset/uuts and coffee/buna are the best indicators for the changes that have been occurring in the homegarden systems of Basketo. As explained by informant farmers, the amounts of uuts in the garden are diminishing. Although bacterial wilt, attack by moles, and prolonged dry periods are known to have had their contributions, the major reason behind the reduction in uuts is the deliberate expansion of buna in the garden. Attracted by the amount of income generated by the cash crop, farmers are planting buna in larger amounts. Uuts is also being pushed out of the system by Xanthosoma saggitifolium (L.) Schott (a recent introduction), which aggressively expands in the garden and also competes at the household level for the staple food role of uuts. Dioscorea sp. and Colocasia esculenta (L.) Schott (sherkka that has been long cultivated) are among the declining crops. On the other hand, Saccharum officinarum L., Zingiber officinale Roscoe, new varieties of Musa acuminata $\times$ balbisiana Colla, and okasha/ koroorima are expanding.

\section{Floristic composition and plant diversity in homegardens}

Survey of the homegardens of the study area yielded a total of 149 species that belong to different habits (i.e., trees, shrubs, herbs, and climbers). Herbaceous forms were found to dominate the homegarden vegetation, with the proportion of trees, shrubs, herbs, and climbers at $29.5 \%, 25.5 \%, 42.3 \%$ and $2.68 \%$, respectively. While $77.9 \%$ of the species found in Basketo homegardens are cultivated, the rest $(22.2 \%)$ are spontaneous (i.e., grow- ing in their own right but tolerated for their actual or perceived use). The average species richness of homegardens is 41 with a minimum of 21 and maximum of 60 .

Analysis of species richness of the planted sections of the gardens reveals that the backyard (alwumppa) has the highest mean species richness (7.52), whereas the highest Shannon's Index value is attained by the vegetation of the first part of the lower side (alts'ana A) (Table 5).

Nine species in Basketo homegardens attained a mean cover abundance value $\geq 1$ (Figure 3 ). Uuts is the species with the highest cover-abundance value, while buna ranks second, indicating dominance of these two species in the homegarden systems.

\section{Homegardens versus other land-use systems}

The floristic survey on homegardens and associated land-use systems (i.e., bamboo lands, woodlands, and sacred forests) yielded a total of 207 plant species (Table 6 ). The number of species recorded from homegardens exceeds that from other land-use systems at a ratio of

Table 4. Number of plant species integrated into Basketo homegardens in the last two decades. Basketo Special Woreda, South Nations, Nationalities, and Peoples Regional State, Ethiopia.

\begin{tabular}{|c|c|c|c|c|c|c|}
\hline \multirow[b]{2}{*}{$\begin{array}{l}\text { Altitude } \\
\text { category } \\
\text { (m) }\end{array}$} & \multirow{2}{*}{ 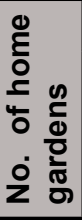 } & \multicolumn{3}{|c|}{ Introduction rate } & \multirow[b]{2}{*}{$\mathbf{F}$} & \multirow[b]{2}{*}{ Sig. } \\
\hline & & $\stackrel{\dot{E}}{\Sigma}$ & $\stackrel{\dot{x}}{\sum^{\pi}}$ & 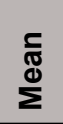 & & \\
\hline $\begin{array}{l}\text { Low } \\
(<1500)\end{array}$ & 15 & 4 & 12 & 8.6 & \multirow{4}{*}{0.676} & \multirow{4}{*}{0.513} \\
\hline $\begin{array}{l}\text { Middle } \\
(1500-1900)\end{array}$ & 35 & 4 & 15 & 8.1 & & \\
\hline $\begin{array}{l}\text { High } \\
(>1900)\end{array}$ & 10 & 6 & 13 & 9.2 & & \\
\hline Total & 60 & 4 & 15 & 8.4 & & \\
\hline
\end{tabular}

Table 5. Species richness and plant diversity in homegarden sections, Basketo Special Woreda, South Nations, Nationalities, and Peoples Regional State, Ethiopia. Lower sides A, B, and C are proximate to a house, middle, and marginal parts of the lower garden section. Significant differences: $1=$ elevated side, $2=$ backyard, $3=$ lower side $A, 4=$ lower side $\mathrm{B}$, and $5=$ lower side $\mathrm{C}$.

\begin{tabular}{|l|c|c|c|}
\hline Homegarden sections & Species richness & Shannon's Index & Evenness \\
\hline Elevated side (aldira) & 6.72 & 1.33 & 0.63 \\
\hline Backyard (alwumppa) & 7.52 & 1.28 & 0.54 \\
\hline Lower side A (alts'ana A) & 7.10 & 1.43 & 0.66 \\
\hline Lower side B (alts'ana B) & 5.88 & 1.20 & 0.65 \\
\hline Lower side C (alts'ana C) & 5.33 & 1.08 & 0.63 \\
\hline Significant diference $(p<0.05)$ & & $1>5 ; 3>4,5$ & \\
\hline
\end{tabular}



Southwestern Ethiopia

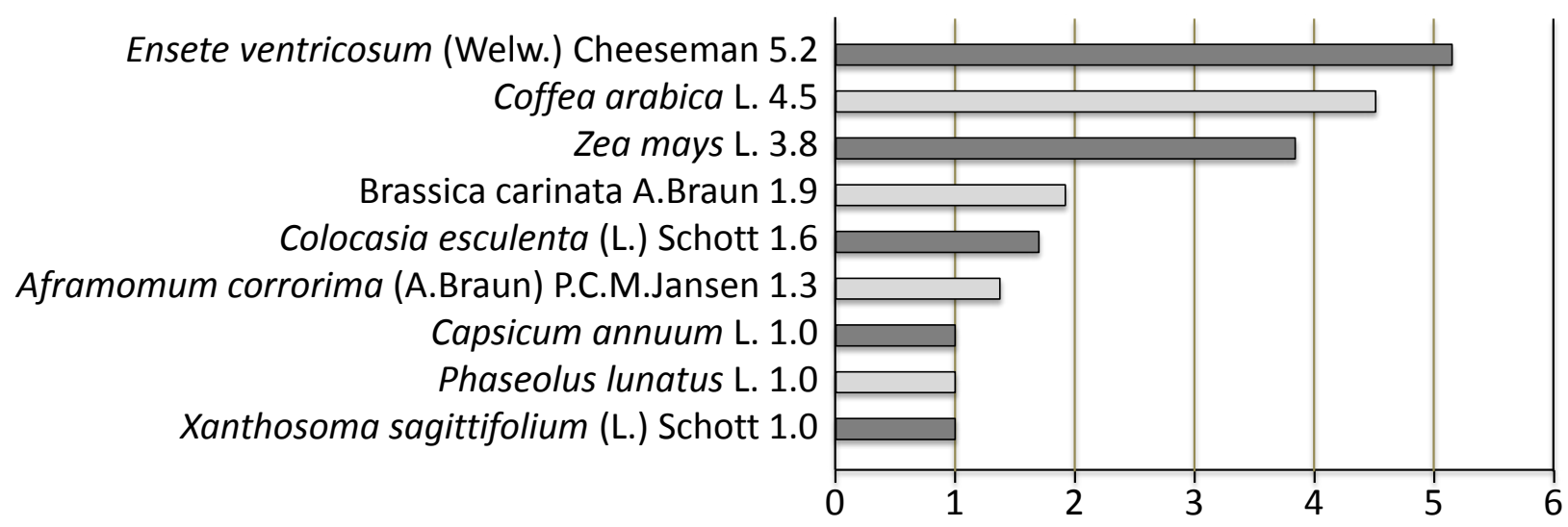

Figure 3. Homegarden species with cover abundance value of 1 or greater in Basketo Special Woreda, South Nations, Nationalities, and Peoples Regional State, Ethiopia.

Table 6. Number of plant families, genera, and species $(n=207)$ recorded at a landscape level in Basketo Special Woreda, South Nations, Nationalities, and Peoples Regional State (SNNPR), Ethiopia.

\begin{tabular}{|l|c|c|c|c|c|c|}
\hline & \multirow{2}{*}{$\begin{array}{c}\text { Home } \\
\text { gardens }\end{array}$} & \multicolumn{4}{|c|}{ Other land-use systems } & \multirow{2}{*}{ Sacred } \\
\cline { 3 - 8 } & forests & Woodlands & $\begin{array}{c}\text { Bamboo } \\
\text { lands }\end{array}$ & Total & Study area total \\
\hline Number of families & 58 & 30 & 26 & 21 & 43 & 67 \\
\hline Number of genera & 127 & 55 & 46 & 29 & 91 & 170 \\
\hline Number of species & 149 & 58 & 52 & 30 & 104 & 207 \\
\hline Family : genera & 0.46 & 0.55 & 0.57 & 0.72 & 0.47 & 0.39 \\
\hline Genera : species & 0.85 & 0.95 & 0.88 & 0.97 & 0.88 & 0.82 \\
\hline
\end{tabular}

149:104. The recorded plant species are distributed in 67 families and 170 genera.

Sorensen's similarity coefficient was computed to assess the floristic similarity among the different land-use systems of Basketo, i.e., homegardens and associated landuse systems. Similarity coefficient values are supposed to range from 0 (no similarity) to 1 (complete similarity). The similarity coefficient was found to lie between 0.1 and 0.59 (Table 7) for the compared pairs. The highest floristic similarity is observed between the sacred forests and bamboo lands, while the lowest similarity is that between the woodlands and bamboo lands.

\section{Discussion}

\section{Design and development of Basketo homegardens}

The organization of homegardens in Basketo is primarily influenced by topographic features, particularly slope. In other words, the nature of the land surface determines which garden section a part of a plot would become when a garden is established. Land feature-garden section relation is evident from the naming of the sections: names of garden sections are formulated in the manner that in- dicates elevation and position or direction relative to the house. Within the Basketo terms aldira (elevated part) and alts'ana (the part running to the lowest point), al- is a shortened form of the term aal (house) while -dira means higher portion of a sloped land, and ts'ana is equivalent to a descending land with steeper slope. Within the names of the other two homegarden sections, alwumppa (backside) and alkara (frontside), the segments -wumppa and -kara are equivalent to back and gate/front side, respectively.

The architecture of Basketo gardens conforms to the vertical and horizontal organization of tropical homegardens as described by several authors (Caballero 1992, Fernandes \& Nair 1990, Gillespie et al. 1993, Jensen 1993, Sommers 1982). A closer look at the horizontal arrangement of plants in the gardens reveals that the positioning of plants is based on a good understanding of the ecological requirements of individual plant species. For example, plants with relatively low water requirements and those that favor rocky grounds are planted at the elevated part of the garden; those with high nutrient requirement are placed around the house; those that thrive in the open are raised at the middle of the extended lower section where the shade effect is low; moisture-loving herbaceous types 
Table 7. Similarity in species composition between different land-use systems of Basketo Special Woreda, South Nations, Nationalities, and Peoples Regional State (SNNPR), Ethiopia.

\begin{tabular}{|l|c|c|c|c|}
\hline Land use systems & HG & SF & WL & BL \\
\hline HG - Homegardens & - & 0.32 & 0.18 & 0.25 \\
\hline SF - Sacred forests & & - & 0.20 & 0.59 \\
\hline WL - Woodlands & & & - & 0.10 \\
\hline BL - Bamboo lands & & & & - \\
\hline
\end{tabular}

that form a dense ground cover are grown at wet margins; and shade-loving shrubby forms are integrated with trees. Such ecological knowledge-based ordering of garden plants appears to be common among traditional communities: identical practices by local societies have been reported from elsewhere (Abdoellah 1990, Christanty 1990, Okigbo 1990). Nevertheless, as the reality in Basketo suggests, factors that define distribution of plants in gardens transcend the plant-environment interaction dimension and enter into the local worldview realm. The planting of only selected plant types in the aldira (elevated part) where the kaasha (thanksgiving) ritual is conducted and also the gender-based restriction that avoids frequent harvesting of uuts from this section are examples to mention.

The establishment of Basketo homegardens begins by planting herbaceous forms, particularly uuts and the garden matures gradually. Since the garden progresses from a bare ground through a herbaceous stage to a farming unit characterized by a diverse mixture of trees, shrubs, and herbs, the development process may be described as successional and cumulative. In terms of plant composition, the proportional contribution of plants of the different habit categories can be put as: Herbs $>$ Trees $>$ Shrubs $>$ Climbers. A closely similar observation was reported from a study in homegardens of Bangladesh (Ali 2005) and forests in Bonga, Ethiopia (Senbeta 2006), except that a higher number of climbers than shrubs was reported in both cases. The dominance of the herbaceous component is the result of the farmers' deliberate strategy of concentrating food producing-plants.

\section{Subsistence role and management of Basketo homegardens}

The homegardens of Basketo belong to the Ethiopian gardens category, which (as noted by Abebe 2005) is characterized by a diverse mixture of crop plants with uuts forming the basic framework. These gardens provide services to the household that range from provision of food through keeping family health and generating income to strengthening social ties and fulfilling spiritual requirements. Irrespective of their size, the farming units are the major suppliers of food to the household. The fact that the population in the area has never experienced serious shortages of food is a good indication of the reliability and sustainability of these agro-ecosystems. Their role of generating income is improving due to changing trading situations resulting in significant implications in terms of local livelihood development since the garden is the major source of household income.

In Basketo, acquiring a homegarden is the most basic requirement that must be met during the transition from boyhood into full-fledged community membership. By implication, other land-use systems are of secondary importance, and therefore their very existence (in most cases) is linked to the homegarden. Usually, the homegarden area is shared with grown-up sons when the father is alive, or handed down to the eldest son when both parents pass away. The inheritor has a responsibility for maintaining the homegarden since it symbolizes the continuity of the family. Therefore, homegardens have a status of heritage and their conversion into other land-use systems is unlikely.

A multitude of management practices are performed in Basketo gardens, such as intensive utilization of space by planting a diverse mixture of plants; regular application of farm-based products to ensure soil fertility; constant weeding, pruning, and cleaning; and also low tolerance to spontaneously growing species. The extra care given to Basketo gardens is linked to shortage of farming land and the consequent heavy dependence on the homegardens. The land-constraint-based intensive management of Basketo homegardens is in agreement with what was expressed by Ali (2005) as an inverse relationship between intensity of cultivation and landholding size. Though the situation in Basketo is in line, to some extent, with the general truth that women are highly involved in the management and are more knowledgeable of gardens (Ali 2005, Asfaw 1997, Brownrigg 1985, Finerman \& Sackett 2003, Mohan 2004, Ninez 1990, Soemarwoto \& Conway 1992, Vogl-Lukasser \& Vogl 2004), Basketo gardens are not the main responsibility of women. Instead, both men and women are in charge of management. As the present trend suggests, an increasing involvement of men is associated with the increased commercialization of garden produce. However, such new developments, when guided by economic rationale and given the dominant decision-making role of men, can lead to drastic changes in the structure of homegardens and erosion of local knowledge.

The established norm of product extraction from homegardens is closely tied to local worldview which, like other traditional societies, is holistic (Abrams \& Primack 2001, Howard 1989, Slikkerveer 1999). The practice of harvesting some crops after holding a thanksgiving ceremony (kaasha), which involves presenting the "first fruits" 


\section{Woldeyes et al. - Homegardens (Aal-oos-gad) of the Basket People of Southwestern Ethiopia}

(a portion of the first harvest) at a ritual site (sacred grove), can be interpreted as a manifestation of the respect dedicated to the earth (that "provides all") and its other components. Gender-based harvest restrictions or those that apply during certain seasons of the year fall within the categories of local resource management practices (Berkes et al. 2000, Colding \& Folke 2001) and have clear conservation implications on plant resources of the area.

\section{Plant diversity of homegardens}

Out of the total 207 plant species recorded from the surveyed landscape of Basketo, $72 \%$ species are maintained in homegardens. This finding is in agreement with the notion that diversity is a cardinal trait of traditional homegardens (Brownrigg 1985). The average species richness of Basketo gardens (40.9) is higher than the richness values 7.0 and 35.7 reported for Jabithenan (Linger et al. 2014) and Sidama (Abebe 2005) gardens of Ethiopia, as well as the values 29.3 and 21.3 reported for Kerala (Peyre et al. 2006) and Cuban (Wezel \& Bender 2003) gardens. The very high species richness difference between Basketo and Jabithenan (Gojjam) gardens is expected, since the latter are from the region in Ethiopia where homegardens are less complex in organization. However, the difference with Sidam gardens of the same region may be related to a higher reliance of the Basketo people on homegardens as a source of diverse products.

In the present study, plant diversity was assessed in the different sections of the garden as opposed to the customary practice of treating the entire garden as a single unit. As alpha diversity (species richness) values of garden sections indicate, the backyard is the most species-rich area, attaining 7.52 mean value for the diversity index. The high species richness observed in the backyard is associated with the planting of different kinds of spices and vegetables as well as care- and fertilizer input-requiring plants such as yam. Species richness tends to decrease in the lower garden part with distance from the house (i.e., from lower side $A$ through lower side $B$ to lower side $C$ ) (Table 5). Decline in diversity of plants in the lower side is a result of growing mainly cereals in largely uniform stands often interplanted with mayts' (Brassica carinata A.Braun) or legumes.

Garden sections differ in additional measures of diversity: Shannon's index $\left(H^{\prime}\right)$ which takes into account the degree of evenness in species abundance, and species evenness $(E)$ which is the ratio of observed to maximum diversity (Magurran 2004). Accordingly, the first part of the lower section (lower side A) exhibits the highest value for Shannon's index and also evenness. The reason behind this is that uuts is not dominant in this part (except in young households where gardens are not yet mature), but rather occurs mixed with buna and other crops. In addition, plants such as tubers, sugarcane, and legumes are planted right at the edge of the section. As can be seen from the significance test on Shannon's index values (Table 5), the elevated side, backyard, and lower side A (all close to the house) of Basketo gardens show resemblance in terms of plant diversity.

\section{Changes in the homegarden system}

Basketo homegardens are in a process of change with respect to plant composition, management practices, and organization. Such change is in compliance with the recognition that homegardens are dynamic systems exhibiting changes through time (Asfaw 2001a, Peyre et al. 2006, Tesfaye 2008, Vogl-Lukasser \& Vogl 2004). The processes of changes occurring in Basketo gardens can be identified as succession-based, expansion-based, introductionbased, and land constraint-related types. The first type of change (succession-based) is somewhat similar to secondary succession (Grime 1979) as there is a progressive alteration in structure and species composition of the vegetation. However, succession in the homegardens is of a contracted type since colonization stage by ruderals (annuals or short-lived perennials that take advantage of disturbance) is avoided or minimized. Additionally, succession is arrested at a certain level through regular disturbance. The raising of uuts followed by buna and then tree species is analogous to the "perennial herbs $\rightarrow$ shrubs $\rightarrow$ trees" sequence in secondary succession of other vegetation systems (Grime 1979). In the course of the process, as pointed out by Jose and Shanmugaratnam (1993), the farmers' role is directing succession rather than fighting it, a management technique based on a deep understanding of ecological processes.

Expansion- and introduction-based changes that are becoming increasingly conspicuous are not driven by ecological factors but by economic ones. Buna is the most rapidly expanding crop at the expense of uuts, which traditionally represents the major staple in the area. The closeness of the cover-abundance value of uuts and buna, 5.2 and 4.5 respectively, shows how buna is rivaling uuts in these gardens (Figure 3). Buna is increasingly being given special emphasis by farmers and agricultural development workers due to the growing tendency to regard the plant as more rewarding, an opinion that is associated with recent improvements in market availability. If the present situation continues, development of monoculture stands of buna will lead to homegarden biodiversity threat. Since a closely similar development was reported from the homegardens of the Sidama Zone of the same region (Abebe et al. 2010), it is not difficult to note that changes with unpredictable impact are occurring at a broad regional level. 
The introduction of new species is also associated with economic motives, i.e., maximizing household income. Agricultural development-related interventions, coupled with farmers' interest in new crops, paved the way for incorporation of $30(20.1 \%)$ homegarden species (Table 3 ). Fruit trees alone account for $30 \%$ of the recent introductions, and their success together with the expansion of the shade-loving buna could lead to a major modification in the structure and composition of homegardens. The average number of recently introduced species is comparable in the three altitudinal zones of the study area (Table 4), an outcome of the closeness (in terms of distance) of the agro-ecological zones as well as the uniformity of agricultural intervention packages.

Land constraints exert an impact in determining the nature of homegardens in a different manner. In Basketo, homegarden land formerly was shared with sons by dividing it along its length (that is from the elevated part down to the wetland margin). Due to the growing shortage of land, however, parents started to retain the wet margin of their garden where they grow koroorima because the spice-yielding plant is a good income-generating crop and requires little labor to manage. Familial land division leads to creation of homegardens that lack a wet margin where plants such as koroorima, sherkka, and wooshi are raised. In response, younger farmers grow koroorima in drier parts of their gardens under the shade of tree species such as Ficus sur Forssk., Ficus vasta Forssk., and Croton macrostachyus Hochst. ex Delile. The overall impact of this change in management appears positive, as the result is more trees in the chain of homegardens as well as the landscape.

In general, the dominance of buna, expansion of some income-generating crops, and increased introduction of crops with potential economic benefits suggest that market factors are currently imposing increasing impacts in dictating the evolution of the homegardens of Basketo.

\section{Conservation role of homegardens as a landscape unit}

In the present study, a total of 207 plant species were recorded from the mosaic landscapes of Basketo. This number is comparable to the number of vascular plant species recorded from Yayu forest (217) (Senbeta 2006), buna forests in southwestern Ethiopia (220) (Woldemariam et al. 2008), and Afromontane rainforests in Kafa (220) (Schmitt et al. 2010). Basketo landscape species diversity is higher than that of Maji forest (146) (Senbeta 2006), Jibat humid Afromontane forest (183) (Burju et al. 2013), and Masha forest (2013) (Assefa et al. 2013). Such high plant diversity is informative of how human-managed ecosystems are important in maintenance of significant level of biological diversity.
Out of the total 207 plant species recorded from the surveyed landscape of Basketo, $72 \%$ of species are maintained in homegardens. The number of species recorded from the homegardens exceeds not only that in other land-use systems (bamboo lands, woodlands, and sacred forests), but also the sum of species from these systems by a margin of $43 \%$. Furthermore, $33(22.2 \%$ of the garden total) species that spontaneously grow in the gardens and that also occur in other land-use systems are tolerated. Maintenance of such self-establishing (not planted) plant species with no immediate use indicates the important role of the homegardens in conserving elements of the natural vegetation of the area.

The level of distribution of species amongst taxa of higher categories (genera and families), which is termed as taxonomic diversity (Magurran 2004), exhibited by the landscape components of Basketo can be used as an indicator of the level of diversity supported by homegardens. The genera-to-species and family-to-genera ratios of individual units of other land-use systems are greater than those of homegardens (Table 6 ) because those units support a smaller number of species. A smaller number of species, in turn, creates a greater likelihood of distribution of component species into different higher-level taxonomic categories (genera, family). On the other hand, the combined flora of other land-use systems exhibits almost identical ratio values to that of homegardens for the mentioned pairs, i.e., 0.88 vs. 0.85 and 0.47 vs. 0.46 . Such results indicate that homegardens support important diversity at higher taxonomic levels despite deliberate concentration of selected useful plant species in the system.

As the floristic similarity analysis results (obtained through Sorensen's similarity index) indicate, homegardens exhibit the highest similarity $(0.32)$ with sacred forests. Out of the 33 plant species identified to be common to both systems, the majority are shrubs and trees with specific use to the household. Given that Basketo sacred forests represent remnants of the natural vegetation of the area, it could be deduced that homegardens had also been derived from an identical vegetation type. Among the four other land-use types, those that exhibit the highest similarity ratio (0.59) are sacred forests and bamboo lands. Bamboo lands share many of the shrubby and tree species of the sacred forests which grow spontaneously.

The floristic similarity observed among land-use systems of the study area is suggestive of considerable interaction among landscape components. Homegardens are the most numerous operational units, always acquired by individual households, and the least prone to conversion into other land-use systems. The agro-ecosystems form a central element of the landscape around which the remaining components are organized. It is through this interlink that homegardens play a pivotal role in shaping the traditional landscape of Basketo. 


\section{Woldeyes et al. - Homegardens (Aal-oos-gad) of the Basket People of Southwestern Ethiopia}

\section{Conclusions}

Homegardens of Basketo are sustainable production units that provide almost everything the household requires for subsistence. As diversity measures indicate, Basketo homegardens are characterized by high plant diversity and are major contributors to maintenance of biodiversity at the landscape level. The ingenious designing of the homegardens in a manner compatible to local topography, the placing of plants in the garden by their ecological requirements, and efficient utilization of space reflect the environmental knowledge local people accumulated through their intimate association of with the surrounding landscape. Basketo homegardens, which are central in the organization of the landscape, are experiencing new dynamics primarily due to economic factors. The process, if allowed to continue unchecked, could result in the deterioration of agrodiversity and associated impacts.

\section{Acknowledgments}

We are thankful to the French Institute of Development Research (IRD) that financially supported the research component of the study through BIODIVALLOC project. Our special gratitude goes to the Basketo people in general and those farmers whose homegardens were used as study units in particular, the district's Administration, and the Agricultural and Rural Development Office of Basketo Special Woreda. The support extended by Prof. Masayoshi Shigeta of Kyoto University that enabled the corresponding author to focus on giving a final shape to the manuscript is highly appreciated. The contributions of Arba Minch University and Addis Ababa University are also well acknowledged.

\section{Literature Cited}

Abdoellah, O. 1990. Home gardens in Java and their future development. Pp. 69-79 in Tropical Home Gardens. Edited by K. Landauer \& M. Brazil. The United Nations University Press, Tokyo, Japan.

Abebe, T. 2005. Diversity in Homegarden Agroforestry Systems of Southern Ethiopia. Ph.D. thesis, Wageningen University, Wageningen, The Netherlands.

Abebe, T., K. Wiersum \& F. Bongers. 2010. Spatial and temporal variation in crop diversity in agroforestry homegardens of southern Ethiopia. Agroforestry Systems 78:309-322. dx.doi.org/10.1007/s10457-009-9246-6

Abrams, N. \& J. Primack. 2001. Cosmology and 21 st. century culture. Science 293(5536):1769-1770. dx.doi. org/10.1126/science. 1063090

Agize, M. 2008. Home Garden Biodiversity with Emphasis on Ethnobotany of Spices, Condiments and Medicinal
Plants in Loma and Gena Bosa Woredas of Dawro Zone, Southern Ethiopia. Masters thesis, Addis Ababa University, Addis Ababa, Ethiopia.

Alexiades, M. 1996. Protocol for conducting ethnobotanical research in the tropics. Pp. 5-18 in Selected Guidelines for Ethnobotanical Research: A field manual. Edited by M. Alexiades. The New York Botanical Garden, Bronx, New York, U.S.A.

Ali, A. 2005. Homegardens in smallholder farming systems: Examples from Bangladesh. Human Ecology 33(2):245-270. dx.doi.org/10.1007/s10745-005-2434-8

Angel-Perez, A. \& M. Mendoza. 2004. Totonac homegardens and natural resources in Veracruz, Mexico. Agriculture and Human Values 21:329-346. dx.doi.org/10.1007/ $\underline{\text { s10460-004-1219-9 }}$

Asfaw, Z. 1997. Survey of indigenous food crops, their preparations and home gardens. Pp. 42-60 in Indigenous African Food Crops and Useful Plants. Edited by B. Okigbo. ICIPE Science Press, Nairobi, Kenya.

Asfaw, Z. 2001a. Origin and evolution of rural homegardens in Ethiopia. Biologiske Skrifter 54:273-286.

Asfaw, Z. 2001b. Home garden in Ethiopia: Some observations and generalizations. Pp. 125-139 in Home Gardens and In Situ Conservation of Plant Genetic Resources in Farming Systems. Edited by J. Watson, \& P. Eyzaguirre. Proceedings of the Second International Home Gardens Workshop, Witzenhausen, Germany.

Asfaw, Z. \& A. Nigatu. 1995. Home gardens in Ethiopia: Characteristics and plant diversity. SINET: Ethiopian Journal of Science 18(2):235-266.

Assefa, A., S. Demissew \& Z. Woldu. 2013. Floristic composition, structure and regeneration status of Masha forest, south-west Ethiopia. African Journal of Ecolology 52:151-162. dx.doi.org/10.1111/aje.12098

Berkes, F., J. Colding \& C. Folke. 2000. Rediscovery of traditional ecological knowledge as adaptive management. Ecological Applications 10(5):1251-1262.

Bernard, H. 2002. Research Methods in Anthropology: Qualitative and quantitative methods. $3^{\text {rd }}$ edition. AltaMira Press, Walnut Creek, California, U.S.A.

Brandt, S. 1996. A model for the origins and evolution of enset food production. Pp. 36-46 in Enset Based Sustainable Agriculture in Ethiopia. Edited by T. Abate, S. Hiebsch \& S. Brandt. Institute of Agricultural Research, Addis Ababa, Ethiopia. 
Brownrigg, L. 1985. Home Gardening in International Development: What the literature shows. League for International Food Education, Washington D.C., USA.

Burju, T., K. Hundera \& E. Kelbessa. 2013. Floristic composition and structural analysis of Jibat humid Afromontane forest, West Shewa Zone, Oromia National Regional State, Ethiopia. Ethiopian Journal of Education and Sciences 8(2):11-33.

Caballero, J. 1992. Maya home gardens: Past, present and future. Ethnoecologia 1(1):35-49.

Capistrano, A. \& G. Marten. 1986. Agriculture in Southeast Asia. Pp. 6-19 in Traditional Agriculture in Southeast Asia: A human ecology perspective. Edited by G. Marten. Westview Press, Boulder, Colorado, U.S.A.

Christanty, L. 1990. Home gardens in tropical Asia, with special reference to Indonesia. Pp. 9-20 in Tropical Home Gardens. Edited by K. Landauer \& M. Brazil. The United Nations University Press, Tokyo, Japan.

Colding, J. \& C. Folke. 2001. Social taboos: "Invisible" systems of local resource management and biological conservation. Ecological Applications 11(2):584-600. dx.doi. org/10.1890/1051-0761(2001)011[0584:stisol]2.0.co;2

Cunningham, A. 1996. Professional ethics and ethnobotanical research. Pp. 19-48 in Selected Guidelines for Ethnobotanical Research: A field manual. Edited by M. Alexiades. The New York Botanical Garden, Bronx, New York, U.S.A.

Curry, J. 2000. Community worldview and rural systems: A study of five communities in lowa. Annals of the Association of American Geographers 90(4):693-712. dx.doi. org/10.1111/0004-5608.00218

Ehret, C. 1979. On the antiquity of agriculture in Ethiopia. The Journal of African History 20(2):161-177. dx. doi. org/10.1017/S002185370001700X

Fernandes, E. \& P. Nair. 1990. An evolution of the structure and functions of tropical home gardens. Pp. 105-114 in Tropical Home Gardens. Edited by K. Landauer \& M. Brazil. The United Nations University Press, Tokyo, Japan.

Finerman, R. \& R. Sackett. 2003. Using home gardens to decipher health and healing in the Andes. Medical Anthropology Quarterly 17(4):459-481. dx.doi.org/10.1525/ maq.2003.17.4.459

Gillespie, A., D. Knudson \& F. Geilfus. 1993. The structure of four home gardens in the Petén, Guatemala. Agro- forestry Systems 24(2):157-170. dx.doi.org/10.1007/ BF00706889

Godbole, A. 1997. Home gardens: Traditional systems for maintenance of biodiversity. Pp. 9-12 in Applied Ethnobotany in Natural Resource Management - Traditional home gardens. Edited by A. Rastogi, A. Godbok \& P. Shengii. International Centre for Integrated Mountain Development, Nepal.

Grime, J. 1979. Plant Strategies and Vegetation Processes. John Willey \& Sons, Chichester, U.K.

Hedberg, I., I. Friis \& E. Pearson. 2009. Editors of Flora of Ethiopia and Eritrea Volume 8. Uppsala University and University of Addis Ababa, Addis Ababa, Ethiopia.

Howard, M. 1989. Contemporary Cultural Anthropology. $3^{\text {rd }}$ edition. Harper Collins Publishers, New York, New York, U.S.A.

Jensen, M. 1993. Soil conditions, vegetation structure and biomass of a Javanese home garden. Agroforestry Systems 24(2):171-186. dx.doi.org/10.1007/BF00706890

Jose, D. \& N. Shanmugaratnam. 1993. Traditional home gardens of Kerala: A sustainable human ecosystem. Agroforestry Systems 24(2):203-213. dx.doi.org/10.1007/ BF00706892

Karyono, I. 1990. Home gardens in Java: Their structure and function. Pp. 138-146 in Tropical Home Gardens. Edited by K. Landauer \& M. Brazil. The United Nations University Press, Tokyo, Japan.

Ker, A. 1995. Farming systems of the African savanna: A continent in crisis. http://www.idrc.ca/en/ev-9355-201-1DO TOPIC.html Accessed 16 February 2010.

Kippie T. 2002. Five Thousand Years of Sustainability? A case study of Gedeo land use (southern Ethiopia). Ph.D. dissertation, Wageningen University, Wageningen, The Netherlands.

Linger, E., Z. Asfaw \& S. Zewudie. 2014. Plant species diversity of homegarden agroforestry in Jabithenan district, North-Western Ethiopia. International Journal of Biodiversity and Conservation 6(4):301-307. dx.doi.org/10.5897/ $\underline{\mathrm{IJBC} 2013.0677}$

Magurran, R. 2004. Measuring Biological Diversity. Blackwell Science, Malden, Massachusetts, U.S.A.

MoA (Ministry of Agriculture). 2000. Agro-Ecological Zones of Ethiopia. Natural Resource Management and Regulatory Department, Ministry of Agriculture, Addis Ababa, Ethiopia. 


\section{Woldeyes et al. - Homegardens (Aal-oos-gad) of the Basket People of Southwestern Ethiopia}

Mohan, S. 2004. An Assessment of the Ecological and Socioeconomic Benefits Provided by Homegardens: A case study of Kerala, India. Ph.D dissertation, University of Florida, U.S.A. http://ufdc.ufl.edu/UFE0007640/00001/1j

Nguyen, Q. 1995. Home garden systems in Vietnam. Pp. 153-163 in Conserving Biodiversity Outside Protected Areas: The role of traditional agro-ecosystems. Edited by $\mathrm{P}$. Halladay \& D. Gilmour. IUCN, Gland, Switzerland.

Ninez, V. 1990. Garden production in tropical America. Pp. 186-192 in Tropical Home Gardens. Edited by K. Landauer \& M. Brazil. The United Nations University Press, Tokyo, Japan.

Okigbo, B. 1990. Home gardens in tropical Africa. Pp. 2140 in Tropical Home Gardens. Edited by K. Landauer \& M. Brazil. The United Nations University Press, Tokyo, Japan.

Peyre, A., A. Guidal, K. Wiersum \& F. Bongers 2006. Dynamics of homegarden structure and function in Kerala, India. Agroforestry Systems 66:101-115. dx.doi. org/10.1007/s10457-005-2919-x

Power, A. \& A. Flecker. 1996. The role of biodiversity in tropical managed ecosystems. Pp. 173-194 in Biodiversity and Ecosystem Process in Tropical Forests. Edited by G. Orians, R. Dirzo \& J. Cushmon. Springer, Heidelberg, Germany. dx.doi.org/10.1007/978-3-642-79755-2 9

Schmitt, C., M. Denich, S. Demissew, I. Friis \& J. Boehmer. 2010. Floristic diversity in fragmented Afromontane rainforests: Altitudinal variation and conservation importance. Applied Vegetation Science 13:291-304. dx.doi. org/10.1111/j.1654-109x.2009.01067.x

Senbeta, F. 2006. Biodiversity and Ecology of Afromontane Rainforests with Wild Coffea arabica L. Population in Ethiopia. Ph.D. thesis, Ecology and Development Series, No. 38. Cuvillier Verlag, Göttingen, Germany.

Slikkerveer, L. 1999. Ethnosciences, 'TEK' and its application to conservation: Introduction. Pp. 169-177 in Cultural and Spiritual Values of Biodiversity: A complementary contribution to the global biodiversity assessment. Edited by D. Posey. Intermediate Technology Publications, London, U.K.
Soemarwoto, O. 1987. Home gardens: A traditional agroforestry system with a promising future. Pp. 157-170 in Agroforestry: A decade of development. Edited by $\mathrm{H}$. Steepler \& P. Nair. ICRAF, Nairobi, Kenya.

Soemarwoto, O. \& G. Conway. 1992. The Javanese homegarden. Journal for Farming Systems Research-Extension 2(3):95-118.

Sommers, P. 1982. The Mixed Garden: The UNICEF home garden handbook. UNICEF, New York, USA.

Tesfaye, B. 2008. The enset (Ensete ventricosum) gardens of Sidama: Composition, structure and dynamics of a traditional poly-variety system. Genetic Resource and Crop Evolution 55(8):1347-1358. dx.doi.org/10.1007/ s10722-008-9333-y

Van der Maarel, E. 1979. Transformation of cover-abundance values in phytosociology and its effect on community similarity. Vegetatio 39:97-114. dx.doi.org/10.1007/ BF00052021

Vogl-Lukasser, B. \& C. Vogl. 2004. Ethnobotanical research in homegardens of small farmers in the alpine region of Osttirol (Austria): An example for bridges built and building bridges. Ethnobotany Research and Applications 2:111-137.

Wassihun, B., Z. Asfaw \& S. Demissew. 2003. Ethnobotanical study of useful plants in Daniio Gade (home-gardens) in Southern Ethiopia. Ethiopian Journal of Biological Sciences 2(2):119-141.

Wezel, A. \& S. Bender. 2003. Plant species diversity of homegardens of Cuba and its significance for household food supply. Agroforestry Systems 57:39-49. dx.doi. org/10.1023/A:1022973912195

Woldemariam, T., T. Borsch, M. Denich, \& D. Teketay. 2008. Floristic composition and environmental factors characterizing coffee forests in southwest Ethiopia. Forest Ecology and Management 255(7):2138-2150. dx.doi. org/10.1016/j.foreco.2007.12.028

Woldeyes, F. 2000. A Study on Biodiversity Management in Daaddegyo (Traditional Homegardens) by Kafecho People of Bonga Area (Southwestern Ethiopia): An ethnobotanic approach. M.S. thesis, Addis Ababa University, Addis Ababa, Ethiopia. 
